The University of San Francisco

USF Scholarship: a digital repository @ Gleeson Library |

Geschke Center

Economics

College of Arts and Sciences

1999

\title{
The Effect of Microenterprise Lending on Child Schooling in Guatemala
}

Bruce Wydick

University of San Francisco, wydick@lucas.usfca.edu

Follow this and additional works at: http://repository.usfca.edu/econ

Part of the Economics Commons

\section{Recommended Citation}

Bruce Wydick. The Effect of Microenterprise Lending on Child Schooling in Guatemala. Economic Development and Cultural Change. Vol. 47, No. 4 (July 1999), pp. 853-869. DOI: 10.1086/452435

This Article is brought to you for free and open access by the College of Arts and Sciences at USF Scholarship: a digital repository @ Gleeson Library | Geschke Center. It has been accepted for inclusion in Economics by an authorized administrator of USF Scholarship: a digital repository @ Gleeson

Library | Geschke Center. For more information, please contact repository@usfca.edu. 


\section{The Effect of Microenterprise Lending on Child Schooling in Guatemala*}

Bruce Wydick

University of San Francisco

\section{Introduction}

In recent years the link between human capital investment and economic growth has grown tighter in the minds of a broad spectrum of economists and development policy makers. Although the precise nature of the relationship between human capital investment and economic growth is still unclear and a subject of much research, it is difficult to find cases in which broadly based economic growth has occurred without substantial levels of investment in human capital. The new growth theory in particular reflects the belief that human capital investment is crucial to economic growth. Since the fundamental work of Robert Lucas, ${ }^{1}$ recent theoretical models now routinely portray human capital investment as a primary engine of economic growth. ${ }^{2}$

Many of these models, however, underemphasize the structure of the microeconomic decision-making process that gives rise to human capital investment. In both developed and developing countries, human capital investment is typically a household-level decision made in the form of schooling for children. For families who operate household enterprises in developing countries this decision involves an economic trade-off between future returns to schooling and the current return to children's labor in the household enterprise. This research analyzes how access to credit in developing countries can affect the child-schooling decision.

Early contributions to the human capital literature such as the works of Gary Becker and Jacob Mincer implicitly assume that well-functioning credit markets allow families to choose optimal levels of human capital investment in children. ${ }^{3}$ However, even as Milton Friedman noted years ago, credit market imperfections may lead to an underinvestment in human capital, since loans for educational purposes are difficult to secure and are based on uncertain and widely varying expected earnings. ${ }^{4}$ 
This notion is supported by the empirical research of J. Behrman, R. Pollak, and P. Taubman, who show that unequal access to credit markets can result in a misallocation of educational investment. ${ }^{5}$ Their results are obtained by contrasting the educational investment behavior of a sample of veterans who enjoyed access to school loans through the GI bill with a subsequent generation who did not enjoy such access to loans.

A large body of research has illustrated how poorly functioning credit markets, especially in developing countries, can result in a significant misallocation of resources by household enterprises. For example, M. Rosenzweig and K. Wolpin show how missing credit markets create an environment in which Indian farmers misallocate inputs into farm production. ${ }^{6}$ In simulations using a CGE model of Moroccan agriculture, A. de Janvry, E. Sadoulet, and M. Fafchamps show that credit constraints accompanied by other market failures distort households' use of both adult and child labor as inputs in agricultural production. ${ }^{7}$

Other recent research has specifically focused on the negative effects of credit market failure on human capital investment in developing countries. For example, Lars Ljungqvist demonstrates how missing credit markets for human capital investment can result in an "underdevelopment trap", in poor countries. ${ }^{8}$ H. G. Jacoby modifies a model developed by $\mathrm{Y}$. Ben-Porath to test the effects of credit constraints on grade completion in Peru. Empirical results from the Peruvian data suggest that unequal access to credit is indeed an important source of inequality in schooling investment. ${ }^{9}$

The logical policy conclusion from this line of research has frequently been for credit market intervention on both efficiency and equity grounds. ${ }^{10}$ As a consequence, an enormous number of targeted credit programs have emerged across the developing world seeking to direct credit toward both the rural and urban informal sectors. ${ }^{11}$ Many of these programs, such as the Grameen Bank in Bangladesh and the ACCION International affiliates in Latin America, have been able to boast of both rapidly increasing participation rates and repayment rates approaching $100 \%$ from their small loans. ${ }^{12}$ As a consequence of the widespread success of microenterprise lending, an agreement was reached in January 1997 in Washington, D.C., between international development agencies, commercial banks, and governmental authorities to channel $\$ 21.6$ billion toward microenterprise programs over the next 8 years. The stated goal of this effort is to extend credit to at least 100 million impoverished households around the world by the year 2005. ${ }^{13}$

But while immense sums of money are being allocated toward microenterprise lending, relatively little formal research has been carried out on the impact the implementation of such programs has had on the economic behavior of the loan recipients. As a result, understanding the impact of targeted credit programs on the economic behavior of households has emerged as an important concern for policy makers. This article focuses on one particular question with respect to changes in eco- 
nomic behavior that may occur with the introduction of microenterprise credit programs: How does credit access by household enterprises affect the schooling decisions these households make for their children?

In contrast with previous work that points to the positive impact of credit access on schooling, the theoretical results of this research show that the effect of credit access may be either positive or negative. In the case of family enterprises we would expect that if working capital constraints are binding, child labor would often be used as a substitute for hired labor. Results show that a major effect of access to credit is that a relaxation of working capital constraints allows the family to substitute hired labor for the labor of children. I will refer to this phenomenon as the "family-labor-substitution effect." 14

However, the theoretical results in this article derive a second and opposite effect of access to credit on child-schooling investment: as a household enterprise becomes more heavily capitalized, the marginal product of family labor increases, raising the opportunity cost of schooling. I refer to this second as the "household-enterprise-capitalization effect.' If the household-enterprise-capitalization effect dominates the family-labor-substitution effect, investment in schooling could theoretically decrease as credit constraints are relaxed for household enterprises.

The main contribution of this research is to show that either one of these two effects of credit on schooling may dominate under different circumstances. In enterprises where the potential for moral hazard by hired labor is high, for example, the family-labor-substitution effect may be small, since hired labor may require intensive supervision. In contrast, because family labor effort directly affects family consumption, it may require less supervision. In addition, families can employ extraeconomic means of inducing an optimal level of labor effort by children. ${ }^{15}$ Thus, in such situations hired labor may be a poor substitute for family labor. The positive effect of access to credit on child schooling may be further mitigated in cases in which borrowed funds are exhausted on large, lumpy investments in machinery or other types of physical capital goods. As investment in physical capital raises labor productivity and increases the opportunity cost of schooling, child schooling may actually decrease as a result of access to credit.

Data to test the effect of access to credit on child schooling were obtained through a firsthand survey of household enterprises carried out in western Guatemala in conjunction with Fundacion para el Desarrollo Integral de Programas Socioeconomicos (Foundation for the Integrated Development of Socioeconomic Programs [FUNDAP]), ${ }^{16}$ a microenterprise lending program that has been operating in the region since 1988. The survey was administered to 236 operators of household enterprises, primarily in and around the rural towns of Quetzaltenango and Totonicapan. Household enterprises in the sample varied greatly in the number of years they have enjoyed access to credit, since FUNDAP has had to slowly introduce its program into different village areas over time, be- 
cause of logistical constraints. This, combined with the fact that the amount of credit a household can borrow from FUNDAP is largely a function of the number of years of borrowing with the institution, provided the setting for a natural experiment to test the effect of increasing levels of credit access on economic behavior in a cross-sectional empirical analysis.

Conclusions from empirical testing using these data show that in general the family-labor-substitution effect appears to dominate to the extent that better credit access generally has a positive effect on child schooling. Yet tests on the survey data confirm that this generally positive impact of access to credit on schooling may be mitigated when hired labor and child labor are not easily substitutable. This occurs in the context of enterprises characterized by a high potential for moral hazard by hired labor, and in households where parents display a preference for imparting skills to child labor rather than to hired labor, such as in the fabrication of traditional products. In the Guatemalan data sample these appear to include household retail enterprises, where hired labor must be continually supervised to prevent theft or lackadaisical sales effort. They also appear to include enterprises such as those that produce traditional cloth and consumer textiles, in which buyers place a heavy emphasis on the quality and detail of work. Furthermore, by imparting skills to children rather than hired labor through apprenticeship-type relationships, parents are more likely to recapture future returns to their effort than they are by training hired workers whose tenure may be short-lived.

Empirical results also confirm the existence of the householdenterprise-capitalization effect. Specifically, they reveal that the likelihood of a child being withdrawn from school for work in a household enterprise is greater in cases in which borrowers use funds for the purchase of capital equipment instead of strictly for working capital purposes.

The rest of this article is organized as follows: Section II presents a two-period household model that endogenously generates an optimal level of child schooling by households, accounting for the possibility of asymmetric information in credit and labor markets. Comparative statics are then carried out to show the conditions under which child schooling will increase or decrease when credit constraints are relaxed. A brief background of the schooling system in Guatemala and a brief description of the survey data collected in Guatemala are provided in Sections III and IV, respectively. Section V presents empirical tests, and Section VI concludes with a summary of empirical findings from the Guatemalan data and suggestions for further research.

\section{A Two-Period Household Model of Child-Schooling Investment}

The following simple model represents a family seeking to maximize income over two periods. In the first period, the parents of the family man- 
age a household enterprise, such as a small farm, retail store, or light manufacturing business. During this first period, the family must decide on the allocation of inputs to the family enterprise, which potentially can include the labor of the household's children. In the second period, the parents retire, the family enterprise ceases production, and the family is supported by the labor market earnings of its children as they enter adulthood. Other motives for borrowing will be left aside in order to focus on the effect of credit access on relieving working capital and physical capital constraints. ${ }^{17}$ Formally, it is assumed that the family maximizes the utility of income in two periods, $Y_{1}$ and $Y_{2}$,

$$
U\left(Y_{1}, Y_{2}\right)=Y_{1}+Y_{2},
$$

subject to

$$
\begin{aligned}
& Y_{1}=\phi(k, L, 1-h)-w L-r k, \\
& Y_{2}=\beta h,
\end{aligned}
$$

and

$$
0 \leq \Omega-w L-r k
$$

where $k$ is capital, $L$ is hired labor, and a family divides the time endowment of its children between family labor $(1-h)$ and schooling, $h$. The family enterprise is faced with a working capital constraint equal to $\Omega$. Exogenously given parameters in the model include the wage rate, $w$, the rental rate of capital, $r$, and the second-period return to schooling, $\beta$. Of particular interest is the production function, $\phi(\cdot)$, which is increasing, twice differentiable, and concave in all three inputs, and is characterized by cross derivatives between inputs such that $\phi_{12}>0, \phi_{13}>0$, and $\phi_{23} \leq$ $0 .{ }^{18}$ The last of these cross derivatives provides analytical flexibility concerning the substitutability of hired labor for family labor. When these constraints are incorporated into a standard Lagrangian framework, the following maximization problem is obtained,

$$
\max _{k, L, h} Z=\phi(k, L, 1-h)-w L-r k+\lambda(\Omega-w L-r k)+\beta h,
$$

and its associated first-order conditions:

$$
\begin{aligned}
& \frac{\partial Z}{\partial k}=\phi_{1}-r(1+\lambda)=0 \\
& \frac{\partial Z}{\partial L}=\phi_{2}-w(1+\lambda)=0,
\end{aligned}
$$




$$
\frac{\partial Z}{\partial h}=-\phi_{3}+\beta=0
$$

and

$$
\frac{\partial Z}{\partial \lambda}=\Omega-w L-r k=0
$$

An interesting note about the first-order conditions is that the cost of family labor is the only one of the three inputs whose shadow price is not inflated if the credit constraint is binding $(\lambda>0)$. This renders family labor a relatively more attractive input in an environment with poorly functioning credit markets. Totally differentiating the system of equations in $(6 \mathrm{a}-\mathrm{d})$ yields an expression for $\partial h / \partial \Omega$, which can be obtained via Cramer's Rule. The sign of this derivative shows the effect on child schooling when the household enterprise gains increased access to credit. This expression is presented in equation (7). (A technical appendix that shows this derivation can be provided by the author on request.)

$$
\operatorname{sign} \frac{\partial h}{\partial \Omega}=\operatorname{sign}\left[\phi_{32}\left(\phi_{11}-\frac{r}{w} \phi_{12}\right)+\phi_{31}\left(\frac{r}{w} \phi_{22}-\phi_{12}\right)\right]
$$

The first effect, given by the first term in equation (7), is the familylabor-substitution effect. The second effect, shown in the second term in equation (7), is the household-enterprise-capitalization effect. The magnitude of the family-labor-substitution effect is influenced by the value of $\phi_{32}$, which indicates the substitutability of hired labor for family labor. The magnitude of the household-enterprise-capitalization effect is given by $\phi_{31}$, which indicates the extent to which child labor is rendered more productive as the household enterprise becomes increasingly capitalized. Note that as $\phi_{31}$ approaches zero, the labor-substitution effect dominates, and child schooling increases with the relaxation of the capital constraint. However, as $\phi_{32}$ goes to zero, the capitalization effect dominates, and children are withdrawn from school because of their increased productivity in the household enterprise.

Therefore, in a test of the model we would expect to see measures of access to credit displaying a positive effect on schooling for household enterprises in which the risk of moral hazard by hired labor is small. Conversely, we would expect to see this generally positive effect of credit mitigated in household enterprises in which hired labor and family labor are not easily substitutable and in enterprises that have used loans to purchase new capital equipment. 


\section{Background: Education and Schooling in Western Guatemala}

Despite efforts by the Guatemalan government to promote school attendance, Guatemala's illiteracy rate is one of the highest in the Western Hemisphere. Estimates by Unesco put the adult illiteracy rate in 1990 at $44.9 \%$, with the rate estimated to be $52.9 \%$ for women. World Bank statistics place Guatemalan illiteracy rates at levels nearly as high as for countries such as Haiti, which have far fewer resources to potentially devote to education. ${ }^{19}$ Illiteracy is particularly high among the rural indigenous peoples of Guatemala, often reaching extremely high levels among some rural village groups.

Guatemalan law dictates that primary schooling, which begins at age 7 and lasts for 6 years, is compulsory. However, this rule is enforced only in the urban areas and is routinely violated by families who believe that it is in the economic interest of the household to withdraw children from school in order to supplement family income. The tendency of families to withdraw their children from school can be observed in Guatemalan school enrollment data. In 1987, for example, the number of students enrolled in primary school as a percentage of all primary-school-aged children was only $77 \%$; for secondary school the figure slips to $21 \% .^{20}$

\section{The Guatemalan Survey}

During the summer months of 1994, I organized and helped carry out a survey of household enterprises in western Guatemala, in and around the towns of Quetzaltenango (population 96,000) and Totonicapan (population 9,000). FUNDAP, a nongovernmental and nonprofit institution, had provided 236 of these household enterprises with a relatively steady source of credit at a $2.5 \%$ monthly interest rate, a rate roughly equal to that charged in large commercial loans in Guatemala's formal financial sector. Virtually all borrowers reported that previous to their association with FUNDAP they had experienced difficulty borrowing in capital markets, able to obtain only small loans from relatives or, in the case of some urban borrowers, very expensive loans from local moneylenders at interest rates as high as $10 \%$ per month. However, the FUNDAP borrowers had received access to credit for varying lengths of time. While some households were located in areas in which FUNDAP had carried out lending operations for up to 6 years, other households were located in village areas where FUNDAP had initiated lending activity only within the last 12 months. An integral component of FUNDAP's credit policy is to release increasing amounts of credit slowly over a sequence of loans to borrowers. This policy, along with FUNDAP's only gradual introduction of credit into different areas in western Guatemala, provided a valuable instrument for ascertaining the impact of varying degrees of credit access.

About two-thirds of the sample consisted of rural borrowers, who were more often productores, frequently involved in the production of 
TABLE 1

Summary Statistics from Guatemalan Survey Data

\begin{tabular}{|c|c|c|c|}
\hline & Total & $\begin{array}{l}\text { Rural } \\
\text { Household } \\
\text { Enterprises }\end{array}$ & $\begin{array}{c}\text { Urban } \\
\text { Household } \\
\text { Enterprises }\end{array}$ \\
\hline Mean age of child (years) & 13.68 & 13.75 & 13.52 \\
\hline Mean schooling of parent (years) & 2.66 & 2.22 & 3.57 \\
\hline Proportion of urban households & .32 & .00 & 1.00 \\
\hline $\begin{array}{l}\text { Mean gross business revenue (Quetzales; } \\
5.73 \mathrm{Q}=\$ 1 \text { ) }\end{array}$ & 3,723 & 3,723 & 3,721 \\
\hline CREDYR (1,000 Quetzales)* & 6.49 & 5.80 & 7.85 \\
\hline \multicolumn{4}{|l|}{ Proportion in sample: } \\
\hline Boys $\dagger$ & .56 & .55 & .56 \\
\hline Retail enterprises & .20 & .06 & .48 \\
\hline Traditional cloth & .27 & .39 & .00 \\
\hline Tailoring & .28 & .41 & .00 \\
\hline Butchers & .06 & .00 & .17 \\
\hline Carpentry & .03 & .04 & .00 \\
\hline Children currently attending school & .69 & .58 & .91 \\
\hline $\begin{array}{l}\text { Children working in household } \\
\text { enterprise }\end{array}$ & .52 & .63 & .26 \\
\hline $\begin{array}{l}\text { Children working in household enter- } \\
\text { prise and not attending school }\end{array}$ & .31 & .41 & .09 \\
\hline
\end{tabular}

* CREDYR is the instrumental-variable-estimated amount of capital borrowed by a household from FUNDAP within the previous 12 months.

$\dagger$ Error during data collection resulted in unrecorded gender on 56 child observations.

traditional and nontraditional textiles, shoes, candles, or furniture. Most of the urban borrowers were comerciantes, selling food, clothes, and a variety of household goods in the city markets.

From this data set, observations of 292 children aged 10-18 were used in the empirical study. This age-group was selected because it was during these years that parents appeared to make decisions regarding the trade-off between continued investment in schooling and work within the household enterprise. Although a few borrowers who were surveyed reported that children had left school to work somewhere other than the family business, these instances were quite rare, since the potential for moral hazard is significantly reduced when children work under the supervision of parents. All children from households in the survey had access to both primary and secondary schooling. However, those from the rural areas faced higher costs of schooling in the form of longer travel to and from schools. The number of children per household between ages 10 and 18 used in the empirical study from each enterprise ranged from one to four.

Statistics in table 1 show the substantial difference in school attendance between urban and rural areas. In urban areas nearly $91 \%$ of children in the sample were still continuing in school, while just $58 \%$ were attending school in the rural areas. In addition, rural areas show a much higher proportion of children working in household enterprises than ur- 
ban areas show-63\% as opposed to $26 \%$. The difference in parental education is also substantial. The formal education of the parent primarily in charge of operating the household enterprise averages 3.6 years in urban areas but only 2.2 years in rural areas.

\section{Empirical Testing}

Empirical tests on the data tried to ascertain the conditions under which better access to credit increases schooling investment in children and the conditions under which this positive effect is mitigated. The survey provided data on children's age and sex, ${ }^{21}$ characteristics of the family and family enterprise, borrowing and income, and current child labor and school activity. Empirical estimations tested for a link between a proxy for access to credit (total credit received during the previous 12 months) and the probability that a child was reported to be withdrawn from school for work in the family enterprise, subject to a vector of control variables that were also expected to influence the schooling decision.

A potential problem with such an estimation, however, is that the amount borrowed by an enterprise may be endogenous to the schooling decision. (A plausible story is that more "motivated" parents may both have the resources to gain better access to credit and keep their children in school longer.) Thus it is necessary to carry out a two-stage estimation, first using exogenous instruments to obtain estimated values for credit access and then using these estimated values to ascertain the effect of credit access on child schooling. The nature of FUNDAP's lending policy gave rise to some obvious variables to use as instruments for credit access. FUNDAP's timing of the introduction of credit into different regions is clearly exogenous to the schooling decision, and the number of years of borrowing greatly determines the amount of credit the institution is willing to release to a borrower. Thus, the number of years a household has had a borrowing relationship with FUNDAP was used as one instrument, along with a measure of gross monthly sales, another factor FUNDAP uses in determining the amount of credit given to a borrower.

There is a potential problem with using estimated variables as righthand-side variables in a maximum-likelihood logit estimation. With a nonlinear estimation, the slope of the logit function is not generally equal to the slope of the distribution function of the estimated variable used in the logit. Because the bias is of second order, however, it is generally believed to be quite small. ${ }^{22}$ But to act as a diagnostic on the results of the logit-estimated parameters, estimations were also carried out using OLS in a linear probability model (which are asymptotically unbiased, although not minimum variance). The logit estimations take the form

$$
\log \left(\frac{P_{i}}{1-P_{i}}\right)=\alpha+\psi \hat{x}_{i}+\boldsymbol{\beta}^{\prime} \boldsymbol{y}_{i},
$$


where $P_{i}$ is the probability that a child is withdrawn from school and working in a household enterprise, or $\operatorname{pr}(W D S C H O O L)=1, \hat{x}_{i}=\boldsymbol{\delta}^{\prime} z_{i}$ and $\hat{x}_{i}$ is a measure of credit access, $z_{i}$ is a vector of exogenous instruments, $\boldsymbol{y}_{i}$ is a vector of control variables, $\alpha$ and $\psi$ are estimated parameters, and $\boldsymbol{\beta}$ and $\boldsymbol{\delta}$ are vectors of estimated parameters. Estimated values of $\psi$ are thus intended to capture the effect of access to credit on the child-schooling decision. The linear probability model, in contrast, uses OLS to estimate

$$
\hat{P}_{i}=\phi+\gamma \hat{x}_{i}+\boldsymbol{\lambda}^{\prime} \boldsymbol{y}_{i}
$$

where $\hat{P}_{i}$ is the estimated probability that child $i$ is withdrawn from school and working in the household enterprise, $\gamma$ is the instrumental variable (IV) estimated effect of access to credit on schooling, and $\boldsymbol{\lambda}$ again is a vector of parameters for the control variables. Results of these estimations are shown in table 2.

Results of the estimations confirm that, in general, increased access to credit reduces the likelihood that a child will be withdrawn from school to work in the household enterprise. The variable CREDYR reflects the total amount of capital borrowed by the household enterprise from FUNDAP in the last 12 months. The estimations in table 2 show the significance of CREDYR at the $99 \%$ confidence level. Using the logit point estimations from the third column in table 2, this implies that an increase in borrowing of 1,000 quetzales (about \$180) would decrease $\operatorname{pr}(W D S C H O O L)$ by approximately $4.7 \%$, with probabilities evaluated at their means. Since the mean level of borrowing by households in the survey is around 6,400 quetzales, it could be estimated that for the average household in the survey, access to credit has reduced the probability of a child being withdrawn from school by roughly 30\%; the OLS estimations indicate a reduced probability of about $17 \%$.

Other variables also appear to significantly affect the child-schooling decision. Most of these make clear intuitive sense and are the findings of other empirical work. Every additional year in the age of a child increases $\operatorname{pr}(W D S C H O O L)$ by $17.0 \%$. An urban location reduces $\operatorname{pr}(W D S C H O O L)$ by $43.7 \%$. The coefficient measuring the impact of parental education carries the expected sign but is not statistically significant. It is interesting that gender has no statistically significant effect on the probability of being withdrawn from school in the sample of the 236 children for whom gender information was available.

What is perhaps more interesting in the estimations in table 2 is the effect of increased lending to specific types of enterprises on $\operatorname{pr}(W D S C H O O L)$. During the course of the survey, owners of retail enterprises expressed a strong personal preference for family labor over hired labor. They maintained that employing nonfamily labor, especially when it was an individual with whom they had had few previous deal- 


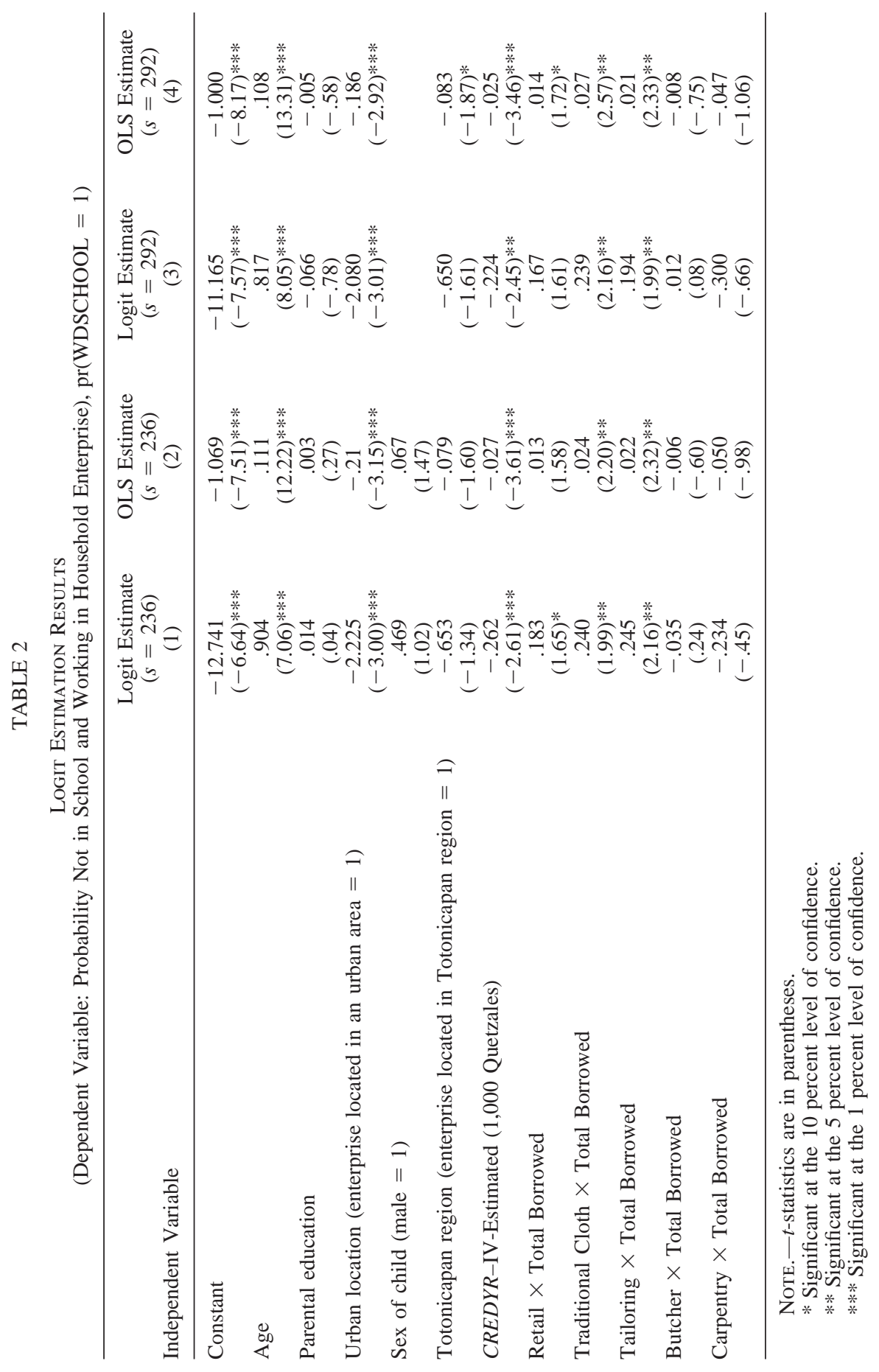

863 
ings, entailed risks of petty theft or shirking by the employee and created the need for supervision. Family labor was believed to be more trustworthy.

The five most common types of enterprises in the sample were included in the estimation. The test of whether increased borrowing by a specific type of enterprise increases $\operatorname{pr}(W D S C H O O L)$ is the significance of the coefficients on the right-hand-side variables $T_{i} \times(C R E D Y R)$, where $T_{i}$ is a dummy variable representing the $i$ th type of enterprise. The estimations in table 2 show statistically significant coefficients on two (and sometimes three) types of enterprises: fabricators of corte (Guatemalan traditional cloth), tailoring shops, and, in some of the estimations, retail enterprises. While the significance of the coefficient measuring the impact of retail enterprise capitalization was expected given the potential for moral hazard that exists within this type of enterprise, the negative impact on child-schooling investment of borrowing by corte manufacturers and tailors was surprising. The result was surprising because hired workers who produce both corte and modern textiles are routinely paid on a piece-rate basis by the owners of the loom on which the cloth is made, a traditional incentive mechanism that mitigates moral hazard problems by hired labor.

Yet follow-up questions to the Guatemalan household survey revealed the statistical results to be indicative of the following phenomenon. The quality of corte is of great concern, since high-quality cloth of intricate detail sells in local markets at prices multiple times higher than less intricate corte. However, the ability to produce corte of fine detail requires years of intensive training. It became clear that parents with the know-how to make such cloth were willing to undertake this kind of long-term apprenticeship with their own children, since they knew that the rewards of the training would ultimately be captured within the household. In this way increases in physical capital may increase the return to trade-specific human capital. However, parents were less willing to undertake such a substantial investment in the training of hired laborers, who might then take these skills to establish their own enterprise. In addition, parents may feel that it is easier for them to capture the returns from this type of apprenticeship than it would be for them to capture the returns from formal schooling. Future returns to formal schooling are likely to occur in urban areas located far away from the household, where expenses of modern living might well diminish remittances to parents.

Credit access may thus help foster the formation of such parent and child apprenticeships, whereas before credit access, formal schooling may have offered the only means of investing in the future labor productivity of children. Although a detailed study of parent and child apprenticeships is beyond the scope of this article, the following point can be made: When there is a high degree of nonsubstitutability between hired 
labor and child labor, credit access may actually reduce investment in schooling rather than facilitate such investment. In other words, the effects of policy interventions to correct imperfections in credit markets may in some cases be dampened by remaining imperfections in labor markets.

The logit estimations in table 3 provide evidence for the householdenterprise-capitalization effect. A priori, we would only expect this effect to be manifest when loans are used to purchase physical capital. Therefore, to identify the existence of the household-enterprisecapitalization effect, the estimations in table 3 are made after splitting the sample between children of borrowers who used loans to make investments in physical capital and those who used borrowed funds for working capital purposes only. ${ }^{23}$ The difference in the coefficients on CREDYR between the two samples shows how the positive effect of access to credit on schooling decreases as household enterprises become increasingly capitalized. In the estimations on the split sample in table 3 , the coefficient on CREDYR in columns 1 and 2 is significantly and strongly negative when borrowed credit is not used to purchase new equipmment. In contrast, the point estimate of the coefficient is statistically insignificant in columns 3 and 4 and even becomes positive in column 4 , when loans are used to purchase new equipment. ${ }^{24}$ Because the estimations in table 3 are in reduced form, the statistical insignificance of the coefficients on CREDYR in columns 3 and 4 is not bothersome; the estimations merely show the mitigating force of household enterprise capitalization on the generally positive effect that greater access to credit has on child schooling.

\section{Conclusion}

The empirical conclusions from this research generally support findings from previous research that access to credit increases schooling investment in children. The major contribution of this research, however, is to show that the relationship between access to credit and schooling investment is not unequivocally positive. Although microenterprise credit programs may alleviate many of the harsh consequences of imperfect information-plagued credit markets, this research shows that investment in child schooling also depends on labor market factors. If the potential for moral hazard exists within household enterprises, families may still prefer to use children's labor rather than hired labor, despite the fact that the relaxation of credit constraints could allow hired labor to be substituted for child labor. The positive effect of credit on child schooling may be further mitigated by the physical capitalization of the household enterprise. Enterprise capitalization increases the return to child labor and thus the opportunity cost of schooling. As a consequence, the relief of credit constraints in a developing country setting like Guatemala does not appear to unambiguously increase investment in child schooling as previous research has suggested. 


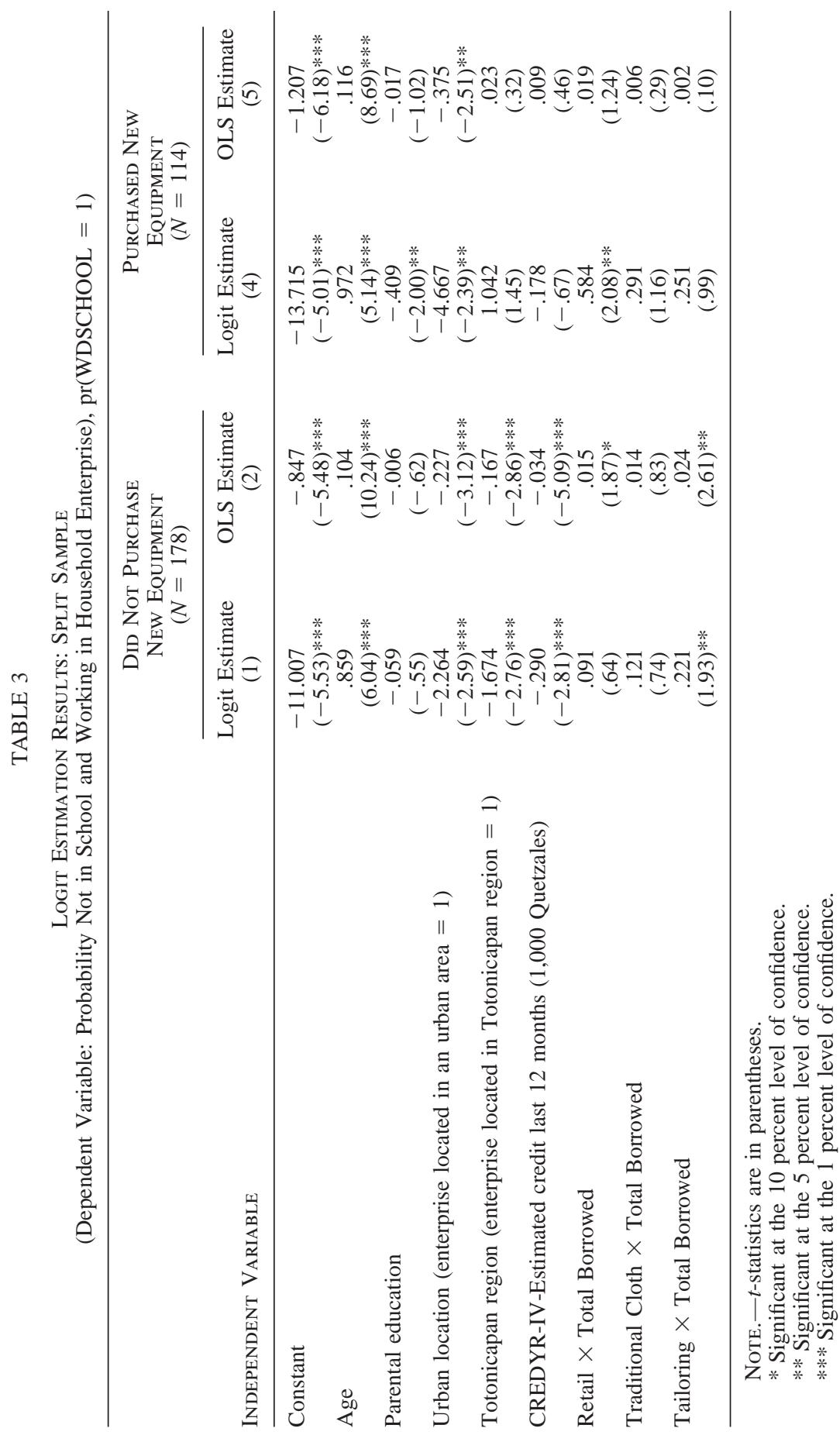

866 
A variety of policies could be considered that might bolster the positive effect of access to credit on schooling. Although most involve real or implicit costs to household producers, they may be justified by the positive externalities associated with education. As a first approach, local policy makers might seek to either increase the minimum age requirement for school attendance or increase penalties to families for child truancy. Policies by targeted credit programs could make continued access to credit contingent on a schooling requirement for children within the household enterprise. The obvious disadvantage of such policies, however, is that they impose costs and constraints on households that may already live only marginally above the subsistence level. Since the pool of potential borrowers for most credit programs is usually very large, alternative lending policies might instead direct lending efforts toward those businesses that can more easily afford to substitute hired labor for family labor.

The aim of future research might be to ascertain if the relationship between access to credit and child schooling presented here is consistent with the impact of microenterprise credit programs operating in other developing countries. This could also include estimations on the return to schooling within the sample region in order to more accurately assess the trade-offs between child labor and investment in schooling.

\section{Notes}

* I would like to thank George Akerlof, Pranab Bardhan, David Card, Alain de Janvry, Ethan Ligon, Betty Sadoulet, seminar discussants at the 1997 Western Economic Association meetings in Seattle, participants in seminars at the University of California, Berkeley, two anonymous referees, and the directors of FUNDAP in Quetzaltenango, Guatemala, for their helpful comments, suggestions, and encouragement. Financial support for field research by the Mellon Foundation is gratefully acknowledged.

1. Robert E. Lucas, Jr., "On the Mechanics of Economic Development," Journal of Monetary Economics 22 (1988): 3-42.

2. See, e.g., Gerhard Glomm and B. Ravikumar, "Public versus Private Investment in Human Capital: Endogenous Growth and Income Inequality,' Journal of Political Economy 100 (1992): 818-34.

3. See Gary S. Becker, Human Capital (New York: National Bureau of Economic Research [NBER], distributed by Columbia University Press, 1975); and Jacob Mincer, Schooling, Experience, and Earnings (New York: NBER, distributed by Columbia University Press, 1974).

4. Milton Friedman, Capitalism and Freedom (Chicago: University of Chicago Press, 1962).

5. J. Behrman, R. Pollak, and P. Taubman, "Family Resources, Family Size, and Access to Financing for College Education," Journal of Political Economy 97 (1989): 398-419.

6. Mark Rosenzweig and Kenneth Wolpin, "Credit Market Constraints, Consumption Smoothing, and the Accumulation of Durable Production Assets in Low-Income Countries: Investments in Bullocks in India,' Journal of Political Economy 101 (1993): 223-44.

7. A. de Janvry, E. Sadoulet, and M. Fafchamps, "Structural Adjustment 
and the Peasantry in Morocco: A Computable Household Model," European Review of Agricultural Economics 19 (1992): 427-53.

8. Lars Ljungqvist, "Economic Underdevelopment: The Case of a Missing Market for Human Capital,' Journal of Development Economics 40 (1993) 219-39.

9. Hanan G. Jacoby, "Borrowing Constraints and Progress through School: Evidence from Peru," Review of Economics and Statistics 76 (1994): 151-60; and Y. Ben-Porath, "The Production of Human Capital and the Life Cycle of Earnings,' Journal of Political Economy 75 (1967): 352-65.

10. Numerous papers have extolled the virtues of microenterprise lending, e.g., Timothy Besley, "How Do Market Failures Justify Interventions in Rural Credit Markets?' World Bank Research Observer 9 (1994): 27-47.

11. It is now estimated that approximately 6 million small entrepreneurs borrow from microenterprise credit programs in developing countries, according to Muhammed Yunas, founder of the Grameen Bank (Pam King, "Microcredit: Small Loans Can Make Difference to Poor of World,' National Times, February 1997).

12. The Grameen Bank, as of January 1997, has a portfolio of over 2 million borrowers, and a repayment rate of $99 \%$ (ibid.). Most of the ACCION affiliates in Latin America enjoy repayment rates of $95 \%$ and above.

13. Paul Lewis, "Small Loans May Be Key to Helping Third World," New York Times, January 26, 1997.

14. Such substitution of labor input would obviously be in the long-term interest of a household if the private rate of return to schooling for children exceeds the interest rate on capital. Estimations on the rate of return to schooling across countries indicate that in developing countries this is nearly always the case. Although specific estimates for Guatemala are difficult to obtain, Psacharopoulos estimates the private real rate of return to primary schooling in Latin America to be an astounding $61 \%$ for primary school and $28 \%$ for secondary school, well above real interest rates in Guatemala. See George Psacharopoulos, Returns to Education (San Francisco: Jossy Bass-Elsevier, 1973), and "Returns to Education: A Further International Update and Implications,' Journal of Human Resources 20 (1985): 583-604.

15. de Janvry et al. point to the example of small farmers in Morocco, who routinely use child labor for animal herding. The potential for moral hazard and the impossibility of labor supervision in herding produce a situation in which "it is difficult to motivate children to take proper care of the animals, unless this is done within the family"' (p. 434). Thus, moral hazard problems render family labor and hired labor imperfect substitutes and, in this particular example, create a market failure for herding labor.

16. FUNDAP is based in Quetzaltenango, Guatemala. One of 120 group lending institutions operating in Latin America, the institution's credit program has a current portfolio of about 2,500 borrowers scattered across eight regional offices in western Guatemala. Although the credit program began operating in 1988 as a result of seed money donated by international development institutions, FUNDAP achieved financial self-sufficiency by 1992. The institution lends to comerciantes (retailers) as well as to productores (light manufacturers). Approximately $25 \%$ of FUNDAP's borrowers are women, and the loan portfolio is about a $70 \% / 30 \%$ mix of rural to urban borrowers.

17. These motives may include borrowing for consumption smoothing purposes, financing weddings or other special occasions, or any other motives apart from obtaining working capital or financing physical capital investments.

18. That $\phi_{12}>0$ and $\phi_{13}>0$ imply complementarity in production between capital and labor. Although this is certainly not universally true, it was shown 
to hold true in the case of production technology in the household enterprises where new capital required additional labor, and increased capitalization was nearly always observed to increase the demand for labor in the enterprise.

19. World Bank, World Development Report (New York: Oxford University Press, 1993).

20. Statistical Abstract of Latin America (Los Angeles: UCLA Latin American Publications, 1995).

21. Data were collected on the gender of children (included in the study), but an error during the field survey resulted in unrecorded gender for 56 children in the sample. Table 2 contains estimations on both the full sample and on the smaller sample that include child gender.

22. See, e.g., Kenneth E. Train, Daniel L. McFadden, and Andrew A. Goett, "Consumer Attitudes and Voluntary Rate Schedules for Public Utilities," Review of Economics and Statistics 63 (1987): 383-91.

23. Because the relatively small number of observations for households with butcher and carpentry enterprises gave rise to estimation problems in the split sample, these right-hand-side variables were dropped in table 3.

24. One possible response to the results presented in table 3 is that household enterprises should still use borrowed capital to substitute hired labor for family labor if the return on schooling is higher than the interest rate, regardless of whether physical capital investment has taken place. However, in practice physical capital investments in household enterprises are sufficiently large and lumpy so that an investment in a new machine, for example, regularly exhausts the degree of credit to which the enterprise has access. Thus, in the case of many household enterprises borrowing from FUNDAP, loans are often provided for purchases of large pieces of capital equipment such as looms, sewing machines, or ovens, but the enterprise remains credit-constrained in the sense that it is unable to borrow enough to equilibrate the rate of return on schooling with the interest rate on borrowed funds. Thus, in these cases the effect of access to credit serves primarily to augment the labor productivity of children within the household enterprise. 
This content downloaded from 138.202.189.84 on Wed, 3 Dec 2014 16:52:10 PM All use subject to JSTOR Terms and Conditions 